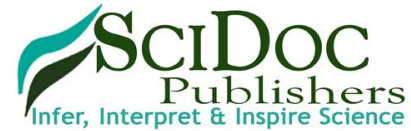

\section{Sexual Maturity Signs and Histological Alterations of Adult Oreochromis Niloticus (Linnaeus, 1758) Fed Probiotic}

Research Article

Mehrim AI*, Khalil FF, Hassan ME

Faculty of Agriculture, Animal Production Department, Mansoura University, Mansoura, Egypt.

\title{
Abstract
}

The accelerated growth of aquaculture industry in the past decades has resulted in environmental damages and low productivity of various aquatic organisms including fish, which seriously need for increased using of dietary probiotics in aquaculture practices. Thus, the present study was conducted to evaluate the effects of the graded levels of a newly dietary probiotic Hydroyeast Aquaculture ${ }^{\circledR}$ on morphological, anatomical of sexual maturation and histological characteristics of the gonads of both sexes of adult Nile tilapia, Oreochromis niloticus for 8 weeks. A total of 240 fish (120 males and 120 females) were separately distributed into eight homogeneous treatments as $0\left(\mathrm{~T}_{1}\right.$, as a control), $5\left(\mathrm{~T}_{2}\right), 10\left(\mathrm{~T}_{3}\right)$, and $15 \mathrm{~g}$ Hydro yeast Aquaculture ${ }^{\circledR} \mathrm{Kg}^{1}$ diet $\left(\mathrm{T}_{4}\right)$ for males and the same levels of tested probiotic $\left(\mathrm{T}_{5}\right.$ as a control, $\mathrm{T}_{6}, \mathrm{~T}_{7}$, and $\left.\mathrm{T}_{8}\right)$ are being for females. The obtained results revealed that both fish sexes fed the different levels of tested probiotic achieved the positively effects on the gonads morphological, anatomical and histological forms compared to fish fed diet free probiotic. Based on the obtained results, it could be concluded the valuable addition of $15 \mathrm{~g} \mathrm{Kg}^{1} \operatorname{diet}\left(\mathrm{T}_{4}\right)$ and $10 \mathrm{~g} \mathrm{Kg}^{1} \operatorname{diet}\left(\mathrm{T}_{7}\right)$ of Hydroyeast Aquaculture ${ }^{\circledR}$ for adult O. niloticus males and females, respectively to enhance the morphological, anatomical of sexual maturation and histological characteristics of the gonads, which consequently lead to realize the sustainability and increase the profitability in the fish hatcheries.

Keywords: Aquaculture; Probiotic; Feed Additives; Nile Tilapia; Fish Reproduction.

Abbreviations: GAFRD: General Authority for Fish Resources Development; BD: Basal Diet; CFU: Colony Forming Units; H: Hematoxyline; E: Eosin; SCY: Spermatocytes; YG: Yolk Globules; YV: Yolk Vesicles; SPZ: Spermatozoa.

\section{Introduction}

Aquaculture is a highly economic yield projects, if achieved correctly. It is the fastest growing production sector all over the world. Where, it's the world wealth coming expansion to reimburse the shortage in animal protein [1]. Globally, total fish production peaked at about 171 million tonnes in 2016, where total aquaculture production has grown extremely during the last fifty years from a production of less than a million tonne in the early 1950 s to 80.0 million tonnes (54.1 million tonnes of finfish, 17.1 million tonnes of molluscs, 7.9 million tonnes of crustaceans and 938.5 metric tonnes of other aquatic animals) by 2016. This level of aquaculture production had a value of US $\$ 232$ billion [2].

Tilapias are among the most produced farmed fish in the world.
Particularly, Nile tilapia, Oreochromis niloticus is one of the most produced and economic freshwater fish species not only in the worldwide, but also in Egypt. Where, the latest Egyptian statistics of fish production revealed that tilapias are considered as the major cultured species; they contributed about $74.52 \%(875.5$ metric tonnes) of the total aquaculture production (1174.8 metric tonnes) [3]. The adaptability to a wide environmental and dietary conditions justifies their success. The expected population growth requires the development of more efficient and productive food production systems [2]. Although tilapia presents the good supra cited attributes for aquaculture, the intensification of the production can be associated with the sufficient of fry by improving the reproductive performance [4].

Feeds play an imperative role in both of the practical and economic aspects of the fish production cycle. Feed additive sectors are

\footnotetext{
*Corresponding Author:

Ahmed I. Mehrim,

Faculty of Agriculture, Animal Production Department, Mansoura University, 35516 Mansoura, Egypt

Tel: +201002915069

E-mail: amehrim2002@yahoo.com

Received: December 24, 2018

Accepted: January 23, 2019

Published: January 28, 2019

Citation: Mehrim AI, Khalil FF, Hassan ME. Sexual Maturity Signs and Histological Alterations of Adult Oreocbromis Niloticus (Linnaeus, 1758) Fed Probiotic. Int J Anat Appl Physiol. 2019;5(1):103-110. doi: http://dx.doi.org/10.19070/2572-7451-1900019

Copyright: Mehrim $\mathbf{A I}^{\circ}$ 2019. This is an open-access article distributed under the terms of the Creative Commons Attribution License, which permits unrestricted use, distribution and reproduction in any medium, provided the original author and source are credited.
} 
growing day after day to realize the better growth and health for fish and shrimp, as well as to meet the potential requirements of the fish farmers [5]. Feed additives may be both nutritive and non-nutritive ingredients and work by either direct or indirect methods on the animal's system $[6,7]$. Currently, there are more sustainable ways to improve the health and performance of tilapia by complementing feeds with functional foods [8]. Functional feed additives are available to regulate growth performance and health of cultivated fish, improve their immune systems, induce physiological benefits, and led to improve aquaculture profit beyond traditional feeds. These functional feed additives including probiotics, prebiotics, immunostimulants, phytogenic substances, enzymes, mycotoxin binders and organic acids $[6,9]$.

Current strategies can include diet supplementation with probiotics or 'live organisms that, when administered in acceptable amounts, confer a health benefit on the host' [10]. Probiotics are very promising in animal production, especially in aquaculture, given the abundance of pathogen and other antigenic stimulus in aquatic environment and their intimate contact with the animals [11]. Using of probiotics is an imperative management tool in aquaculture sector, but their effectiveness depends on understanding the nature of competition between species or strains. Probiotics exhibited promising application in aquaculture, but still needs extensive attempts of research [12]. Many researches were increasable conducted into the use of probiotics for aquaculture with the demand for environment-friendly sustainable aquaculture ${ }^{1}$. Furthermore, nowadays probiotics are quite commonplace in health promoting "functional foods" for humans, as well as therapeutic, prophylactic and growth supplements in animal production and human health [13, 14]. Where, the method of probiotic establishment can be summarized in three steps, attraction, association into the surface secreting gel and ended by attachment to animal tissue cells [15].

Probiotics demonstrated their successes in human and animal feeding practices and recently gained attention in aquaculture [5]. Thus, several types of dietary probiotics were used of different fish species, partially in $O$. niloticus for improving the growth performance $[16,17]$, water quality [18, 19], physiological [20, 21], and immune responses [4, 22], and intestinal morphology [23, 24]. However, few attempts have been attentive on the possible role of probiotic on the reproductive development with special emphasis to the marine [25] or ornamental fish [26-28]. Whereas the effects of probiotics on freshwater fish species have been investigated to a limited extent $[29,30]$. Although, many applications of probiotics in aquaculture more recently documented by Dawood et al., [31] not included the reproductive performance in pre-spawning or spawning stages of the fish. Moreover, in our knowledge not any research was focused on the effect of probiotics on the morphological, anatomical and histological traits of the fish gonads in the pre-spawning stage, as the potential biological indicators for the reproductive performance of broodstock in the spawning period. Consequently, the objectives of the present study were unique to evaluate the effects of the graded levels of a newly commercial dietary probiotic Hydroyeast Aquaculture ${ }^{\circledR}$ for 8 weeks on both sexes of adult Nile tilapia $O$. niloticus (in the prespawning stage), concerning their morphological, anatomical of sexual maturation and histological characteristics of the gonads.

\section{Materials and Methods}

\section{The Experimental Management}

Both sexes of adult Nile tilapia, O. niloticus with an average initial body weight $(83.4 \pm 0.001 \mathrm{~g})$ for males and $(80.1 \pm 0.002)$ for females. Fish were purchased from the Integrated Fish Farm at Al-Manzala (General Authority for Fish Resources Development (GAFRD) - Ministry of Agriculture) Al-Manzala, Al-Dakhalia Governorate, Egypt. Fish were stocked into a rearing tank for two weeks as an adaptation period, during that fish were fed a commercial basal diet (BD). A total of 240 fish (120 males and 120 females) were separately distributed into eight homogeneous treatments (as three replicates (tanks) per treatment, Table 1). Fish were stocked at 10 fish $\mathrm{m}^{3}$ per tank. Each tank $\left(1 \mathrm{~m}^{3}\right.$ in volume) was supplied with an air stone connected to an electric compressor. Waste was removed from each tank by siphoning, then fresh underground water was used to change one third of the water every day.

The tested probiotic, Hydroyeast Aquaculture ${ }^{\circledR}$ formula was comprised of oligosaccharides (50,000 ppm); enzymes (amylase $3.7 \times 10^{6}$, protease $5 \times 10^{5}$, cellulose $2 \times 10^{5}$, pectinase $1 \times$ $10^{5}$, xylanase $1 \times 10^{4}$, phytase $3 \times 10^{3}$ units $\left.\mathrm{Kg}^{1}\right)$; live yeast $(5$ $\times 10^{12}$ colony forming units $\left.(\mathrm{CFU}) \mathrm{Kg}^{1}\right)$; and probiotics bacteria (Lactobacillus acidophilus, Bifedobacterium longhum, B. thermophylu, and Streptococcus faecium $22.5 \times 10^{8} \mathrm{CFU} \mathrm{\textrm {Kg } ^ { 1 }}$ for each). It was produced by Agranco corp., Gables, International Plaza Suite, No. 307, 2655 Le Jeune Rd., $3^{\text {rd }}$ Floor, Coral Gables, Fl 33134, USA.

The commercial BD used in the present study contains $25 \%$ crude protein, which was purchased from Al-Manzala manufacture for fish feed, the Integrated Fish Farm at Al-Manzala (GAFRD Ministry of Agriculture), Al-Dakhalia Governorate, Egypt. The

Table 1. Details of the experimental treatments.

\begin{tabular}{|c|c|}
\hline Treatment & Details \\
\hline $\mathrm{T}_{1}, \hat{\jmath}$ & Basal diet (BD) $+0.0 \mathrm{~g}$ Hydroyeast Aquaculture ${ }^{\circledR} \mathrm{Kg}^{1}$ diet (as a control) \\
\hline $\mathrm{T}_{2}, \boldsymbol{O}^{\lambda}$ & Basal diet $(\mathrm{BD})+5.0 \mathrm{~g}$ Hydroyeast Aquaculture ${ }^{\circledR} \mathrm{Kg}^{1}$ diet \\
\hline $\mathrm{T}_{3}, \hat{\sigma}$ & Basal diet $(\mathrm{BD})+10.0 \mathrm{~g}$ Hydroyeast Aquaculture ${ }^{\circledR} \mathrm{Kg}^{1}$ diet \\
\hline $\mathrm{T}_{4}, \hat{0}$ & Basal diet $(\mathrm{BD})+15.0 \mathrm{~g}$ Hydroyeast Aquaculture ${ }^{\circledR} \mathrm{Kg}^{1}$ diet \\
\hline $\mathrm{T}_{5}$, 우 & Basal diet $(\mathrm{BD})+0.0 \mathrm{~g}$ Hydroyeast Aquaculture ${ }^{\mathbb{R}} \mathrm{Kg}^{1}$ diet (as a control) \\
\hline $\mathrm{T}_{6},+$ & Basal diet $(\mathrm{BD})+5.0 \mathrm{~g}$ Hydroyeast Aquaculture ${ }^{\circledR} \mathrm{Kg}^{1}$ diet \\
\hline $\mathrm{T}_{7},+9$ & Basal diet $(\mathrm{BD})+10.0 \mathrm{~g}$ Hydroyeast Aquaculture ${ }^{\circledR} \mathrm{Kg}^{1}$ diet \\
\hline $\mathrm{T}_{8},+$ & Basal diet $(\mathrm{BD})+15.0 \mathrm{~g}$ Hydroyeast Aquaculture ${ }^{\circledR} \mathrm{Kg}^{1}$ diet \\
\hline
\end{tabular}


commercial BD is consisted of some ingredients such as yellow corn, rice bran, soybean meal (44\%), fish meal (65\%), salts, calcium carbonate, vegetable oil, vitamins and minerals premix, Di-nitro bio (Anti oxidant) and Bintonite (as banding agent) according to the manufacture's formula. The commercial diet was ground to add the different levels of tested probiotic, Hydroyeast Aquaculture $^{\circledR}$ as shown in Table 1, and then all diets were repelleted. The experimental diets were introduced manually twice daily at 9.0 am and $15.0 \mathrm{pm}$ into $3 \%$ of the fish total biomass.

\section{Secondary Sexual Maturation Characteristics}

Five males and five females of $O$. niloticus in each treatment were randomly chosen and anaesthetized by transferring into a small plastic tank containing $10 \mathrm{~L}$ water supplemented with $3 \mathrm{~mL}$ pure clove oil (dissolved in $10 \mathrm{~mL}$ absolute ethanol). Then, the secondary sexual maturation charsteristics were recorded by digital camera after four weeks and at the end of the experiment $\left(8^{\text {th }}\right.$ week). However, the anatomical observations of both sexes were recorded only at the end of the experiment. Where, both fish sexes were anaesthetized and sacrificed for the anatomical examination. The digital camera was used for recording the secondary sexual maturation and anatomical signs in the experimental fish, CASIO, Exilim optical 3x, 6.0 Mega pixels, 2.5" LCD, Anti-shake DSP, CASIO Computer Co., LTD., Tokyo, Japan.

\section{Gonads Histological Examinations}

At the end of the experiment ( $8^{\text {th }}$ week), fish males and females were anaesthetized by the same above anesthetic and sacrificed, where the target organs (gonads) were sampled. Samples were fixed in $10 \%$ neutralized formalin solution followed by washing with tab water, then dehydrated by different grades of alcohol (70, 85, 96 and 99\%). Samples were cleared by xylene and embedded in paraffin wax. The wax blocks were sectioned to six microns. The sections were stained by hematoxyline $(\mathrm{H})$ and eosin $(\mathrm{E})$, and then subjected to a histological examination for gonads (testis and ovaries) according to Roberts [32].

\section{Results}

\section{Morphological of Secondary Sexual Maturation Characteristics}

Male: Morphologically, the secondary sexual maturation signs of adult males $O$. niloticus at the $4^{\text {th }}$ week were illustrated in Figure 1 ( $a, b, c$ and d); while Figures (e, f, g and h) showed these signs at the $8^{\text {th }}$ week (the end of the experiment), which were appeared as dispersing the red color patches on the ventral side, pectoral fins and caudal fin. These signs gradually increased by adding graded levels of the tested Hydroyeast Aquaculture ${ }^{\circledR}$ probiotic especially in $\mathrm{T}_{4}$ (15g probiotic $\mathrm{Kg}^{1}$ diet) compared to the control treatment free inclusion of tested probiotic $\left(\mathrm{T}_{1}\right)$.

Female: The secondary sexual maturation signs of adult females $O$. niloticus at the $4^{\text {th }}$ week were illustrated in Figure 2 (a, b, c and d); while Figures (e, f, g and h) showed these signs at the end of the experiment ( $8^{\text {th }}$ week), which were appeared as increasing the abdomen, project the genital orifice and the eggs emerged from it. These signs gradually increased by adding the graded levels of the tested probiotic especially in $\mathrm{T}_{7}\left(10 \mathrm{~g}\right.$ probiotic $\mathrm{Kg}^{1}$ diet $)$ compared to the control treatment free from the tested probiotic $\left(\mathrm{T}_{5}\right)$.

\section{Anatomical of Secondary Sexual Maturation Characteristics}

Male: Anatomically, the sexual maturation signs of adult males $O$. niloticus at the end of the experiment $\left(8^{\text {th }}\right.$ week) were illustrated in Figure 3 ( $\mathrm{a}, \mathrm{b}, \mathrm{c}$ and $\mathrm{d}$ ), which showed the biggest testis in $\mathrm{T}_{4}, \mathrm{~T}_{3}$ and $\mathrm{T}_{2}$ compared to the control group $\left(\mathrm{T}_{1}\right)$. These signs reflected the positive effects of dietary supplementation of the graded levels of the tested probiotic, especially in $\mathrm{T}_{4}$ compared to the control treated diet free from the tested probiotic $\left(T_{1}\right)$.

Female: The sexual maturation signs of adult females $O$. niloticus at the end of the experiment were illustrated in Figure 4 (a, b, c and d), which showed maturation green-yellowish eggs in fish ovaries especially in $\mathrm{T}_{7}$ followed by $\mathrm{T}_{6}$ and $\mathrm{T}_{8}$ compared to the control group $\left(\mathrm{T}_{5}\right)$. These signs reflected the positive effects of dietary graded levels of tested probiotic especially in $\mathrm{T}_{7}$ compared to the control diet free from the tested probiotic $\left(\mathrm{T}_{5}\right)$.

\section{Histological Examination of the Gonads}

Testes: Testes of adult males O. niloticus fed BD only $\left(\mathrm{T}_{1}\right.$, as a control) showed normal structure of seminiferous tubules filed with spermatocytes (scy) (Figure 5a). Yet, dietary supplementation of $5 \mathrm{~g}$ Hydroyeast Aquaculture ${ }^{\circledR}$ probiotic $\mathrm{Kg}^{1}$ diet $\left(\mathrm{T}_{2}\right)$ showed normal structure of seminiferous tubules filed with scy and spermatids (st) (Figure 5b), which cleared by microscopic high magnification (Figure 5c). However, adult males O. niloticus fed $10 \mathrm{~g}$ probiotic $\mathrm{Kg}^{1}\left(\mathrm{~T}_{3}\right)$ showed normal structure of seminiferous tubules, lumen which, filed with scy and st (Figure 5d), whereas in the same treatment $\left(\mathrm{T}_{3}\right)$, microscopic high magnification revealed clearly scy and st within the lumen of seminiferous tubules (Figure 5e). Meanwhile, fish fed probiotic at level of $15 \mathrm{~g} \mathrm{Kg}^{1} \operatorname{diet}\left(\mathrm{T}_{4}\right)$ showed normal structure of semineferous tubules, lumen filed with scy and st and interstitial tissue (Figure 5f). Also, by high magnification in the same treatment $\left(\mathrm{T}_{4}\right)$ showed spermatozoa (spz) absolutely, cleared in the lumen of seminiferous tubules (Figure $5 \mathrm{~g}$ ). Thus, it could be noted that all of these histological development in testis of experimental fish due to dietary supplementation of tested probiotic.

Ovary: The histological examination in ovaries of adult females O. niloticus fed $\mathrm{BD}$ (as a control, $\mathrm{T}_{5}$ ) showed normal structure of ovarian lamellae, which contains oocytes at various stages of oogenesis (Figure 6a), as well as, in the same treatment $\left(\mathrm{T}_{5}\right)$ by high magnification Figure (6b) showed oocytes in primary stage. However, fish fed Hydroyeast Aquaculture ${ }^{\circledR}$ probiotic at level of $5 \mathrm{~g} \mathrm{Kg}^{1}\left(\mathrm{~T}_{6}\right)$ showed normal structure of ovarian lamellae, which contains oocytes at various stages of oogenesis and oocytes in yolk vesicles (YV) stage (Figure 6c). Yet, fish fed dietary probiotic at level of $10 \mathrm{~g} \mathrm{Kg}^{1}\left(\mathrm{~T}_{7}\right)$ showed oocytes in yolk globules (YG) and YV stages (Figure 6d). From other hand, fish fed $15 \mathrm{~g}$ probiotic $\mathrm{Kg}^{1}$ diet $\left(\mathrm{T}_{8}\right)$ showed oocytes in late vitellogenic stage (Figure 6e) and in ripening stage (Figure 6f).

\section{Discussion}

Sexual dimorphic characteristics vary, but color patterns are useful to differentiate some, and urogenital features permit the sexing of 
Figure 1. Secondary sexual maturation signs (arrows) of adult males $O$. niloticus, (a) $T_{1}$ as a control; (b) $T_{2}$; (c) $T_{3}$ and (d) $\mathrm{T}_{4}$ at the $4^{\text {th }}$ week, and (e), (f), (g) and (h) at the $8^{\text {th }}$ week of the experiment.
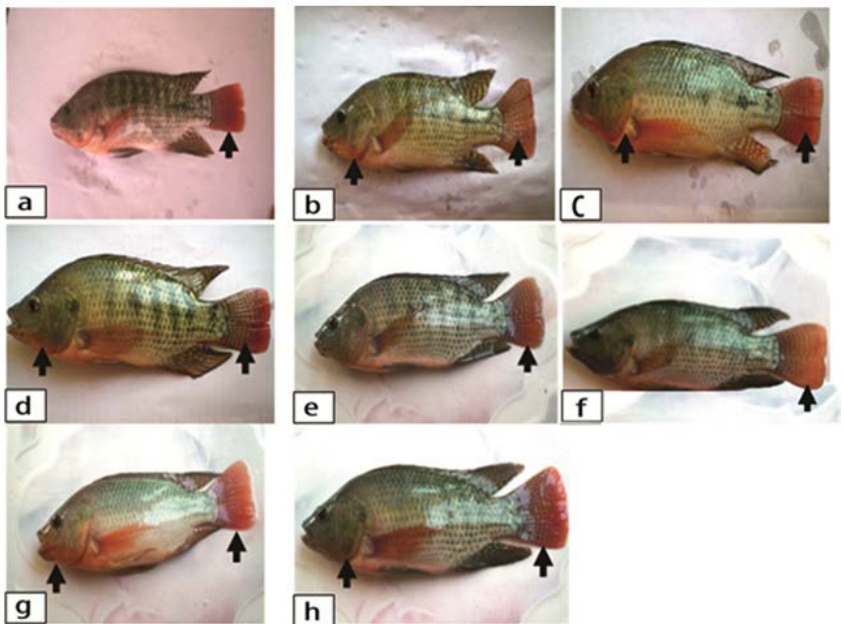

Figure 2. Secondary sexual maturation signs (circles) of adult females $O$. niloticus, (a) $T_{5}$ as a control; (b) $T_{6}$; (c) $T_{7}$ and (d) $T_{8}$ at the $4^{\text {th }}$ week, and (e), (f), (g) and (h) at the $8^{\text {th }}$ week of the experiment.
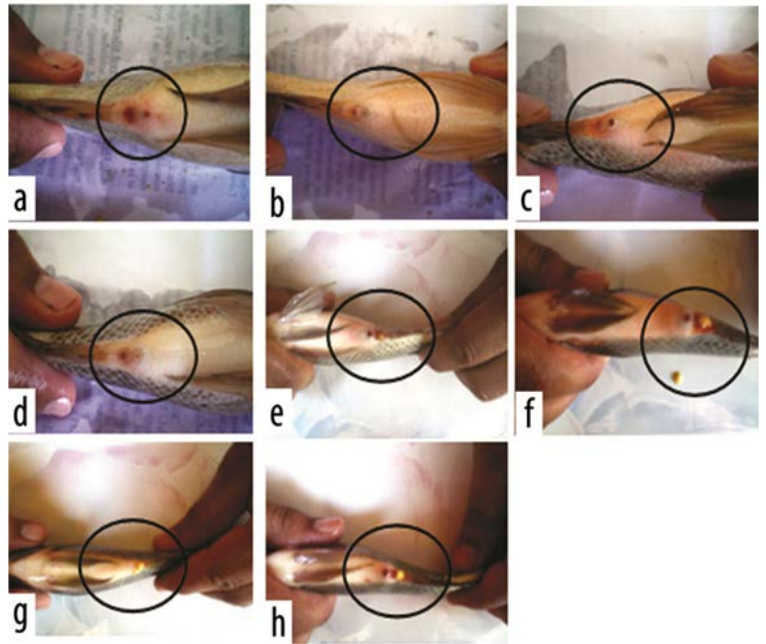

Figure 3. Testes anatomical signs (arrows) of adult males $O$. niloticus at the $8^{\text {th }}$ week of the experiment, (a) $T_{1}$ as a control; (b) $T_{2} ;$ (c) $T_{3}$ and (d) $T_{4}$.
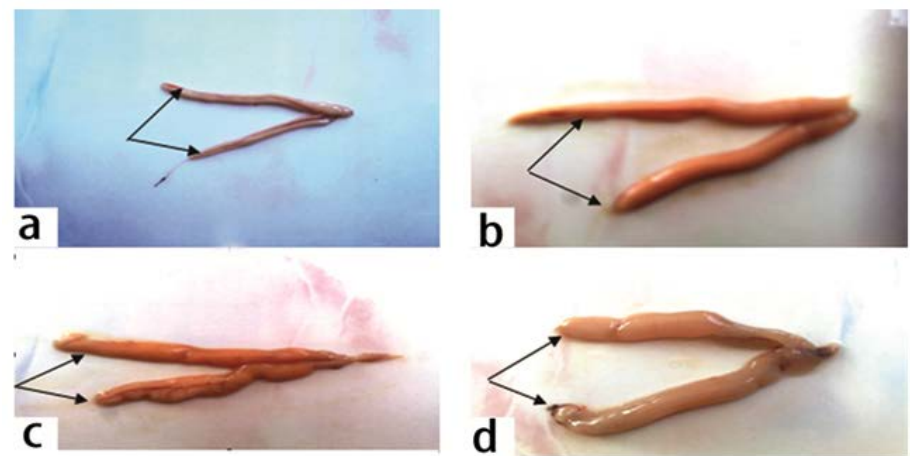
Figure 4. Ovaries anatomical signs (arrows) of adult females $O$. niloticus at the $8^{\text {th }}$ week of the experiment, (a) $\mathrm{T}_{5}$ as a control; (b) $\mathrm{T}_{6}$; (c) $\mathrm{T}_{7}$ and (d) $\mathrm{T}_{8}$.

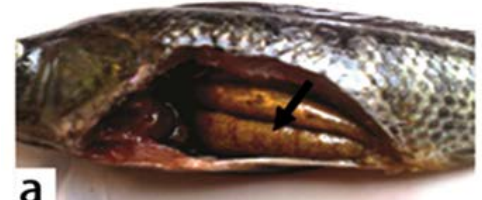

a

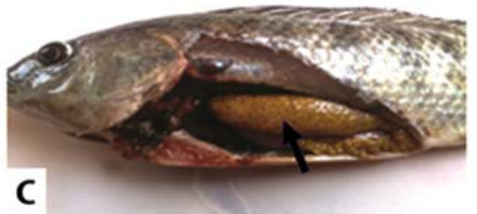

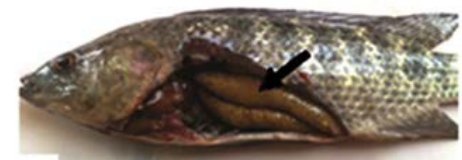

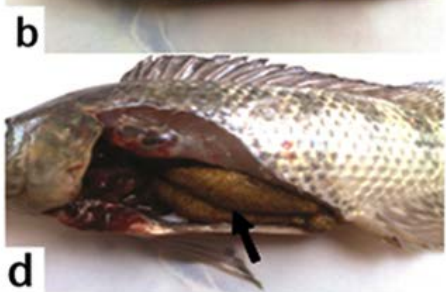

Figure 5. Transverse section in testes of adult $O$. niloticus, (a): fed BD ( $\mathrm{T}_{1}$, control) $(\times 100$, $\mathrm{H \& E}$ stains); (b): fed 5g probiotic $\mathrm{Kg}^{1} \operatorname{diet}\left(\mathrm{T}_{2}\right)\left(\times 100, \mathrm{H} \& \mathrm{E}\right.$ stains); (c): High magnification of $\mathrm{T}_{2}$ (b) ( $\times$ 400, H\&E stains); (d): fed 10g probiotic Kg${ }^{1}$ diet

$\left(T_{3}\right)(\times 100, H \& E$ stains $)$; $€$ : High magnification of $T_{3}(d)(\times 400$, H\&E stains $)$; $(f):$ fed $15 g$ probiotic $\mathrm{Kg}^{1}$ diet $\left(T_{4}\right)(\times 100$, H\&E stains); (g): High magnification of $T_{4}(f)(\times 400, H \& E$ stains $)$.
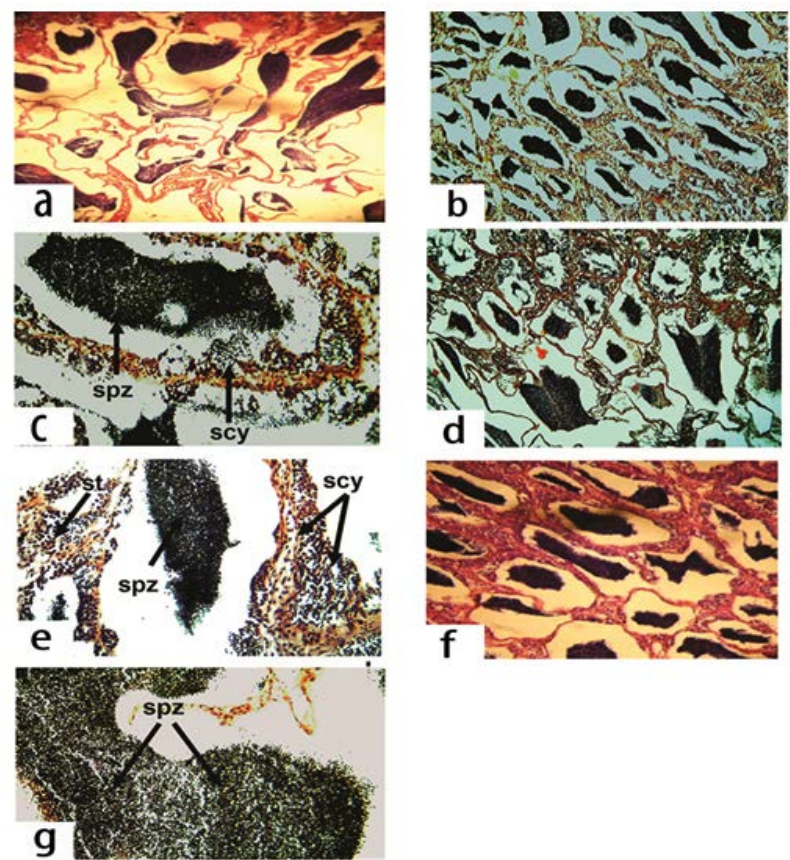

Figure 6. Transverse section in ovary of adult $O$. niloticus (a): fed BD ( $\mathrm{T}_{5}$, control) ( $\times 80, \mathrm{H} \& \mathrm{E}$ stains); (b): High magnification of $\mathrm{T}_{5}\left(\times 160, \mathrm{H} \& \mathrm{E}\right.$ stains); (c) fed $5 \mathrm{~g}$ probiotic $\mathrm{Kg}^{1} \operatorname{diet}\left(\mathrm{T}_{6}\right)\left(\times 160, \mathrm{H} \& \mathrm{E}\right.$ stains); (d): fed 10g probiotic $\mathrm{Kg}^{1} \mathrm{diet}$ $\left(\mathrm{T}_{7}\right)(\times 400, \mathrm{H} \& \mathrm{E}$ stains $)$; $€$ : fed $15 \mathrm{~g}$ probiotic $\mathrm{Kg}_{1} \operatorname{diet}\left(\mathrm{T}_{8}\right)(\times 400, \mathrm{H} \& \mathrm{E}$ stains $)$.
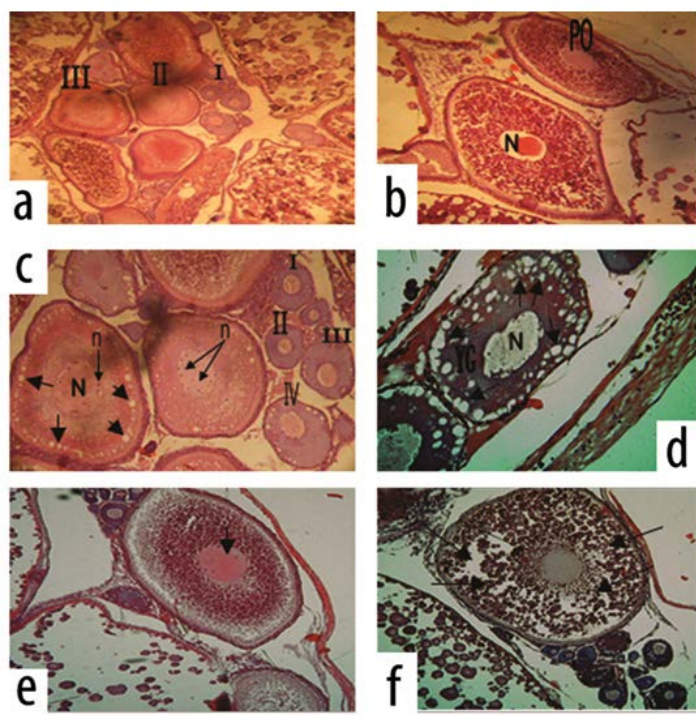
adult fish. The papilla of males is slightly larger, more pointed, and has a single terminal urogenital opening, whereas the papilla of the female has a subterminal urinary pore and a horizontal slit like genital opening midway between the tip and anus [33]. Present findings of morphological sexual maturation characteristics of adult males and females' $O$. niloticus increased gradually by dietary tested probiotic especially in $\mathrm{T}_{4}$ and $\mathrm{T}_{7}$ respectively, compared to the control treatments $\left(\mathrm{T}_{1} \& \mathrm{~T}_{5}\right)$ at $4^{\text {th }}$ week or at $8^{\text {th }}$ week, as well as anatomical sexual maturation signs at $8^{\text {th }}$ week, which reflected the maturation of gonads and highly related with the reproductive physiological findings reported in a complementary study to the present study by Mehrim et al., [29].

In all the Oreochromis spp. males grow faster and to a larger size than females. This difference in growth is pronounced after the onset of sexual maturity, and several factors are considered relevant [33]; as the importance of territory in reproductive strategy, which may have favored the selection of larger males; the anabolic effects of androgens; the greater energy requirement for egg formation than for testicular development; the lack of feeding during brooding by females. In adult tilapia males the genital papilla has only one opening (the urinary pore of the urethra) through which both milt (sperm) and urine pass. However, in females the eggs exit through a separate oviduct and only urine passes through the urinary pore. Examination of the genital opening can therefore be used to determine the sex of tilapia, once a size of approximately 30 gram is reached [34]. Moreover, the description of stages provides information about the extension of the gonad in relation to the body cavity as well as the width of the gonad at the widest point. Relative size, shape, consistency and structure are the most important characteristics distinguishing maturity stages. Differences in colour between maturity stages that occur during development due to yolk and sperm formation. The colour is a more prominent trait in females than males, as the variation in colour between testes in different maturity stages is subtler than for ovaries [35].

Gonadal development is a continuous process, but specific histological characteristics can be used to classify stages of gonadal development during the reproductive cycle [35]. Thus, several stages of spermatogenesis in adult males' O. niloticus (spermatocytes, spermatid and spermatozoa) in the present study similar with those reported by Msiska [36]. In addition, secondary spermatocytes were illustrated by darkly staining chromatin as in other teleost fish. Meanwhile, spermatozoa were concentrated in the lumen $[37,38]$. In the seminiferous epithelium, spermatogenesis takes place within cysts or spermatocysts that are formed when a single spermatogonia (primary or type A spermatogonia) is completely enveloped by Sertoli cells [39, 40]. Spermatogenesis is a complex biological process of cellular transformation that produces male haploid germ cells from diploid spermatogonial stem cells [41, 42]. From the histological point of view, at the present study, several stages of spermatogenesis were detected in adult males' $O$. niloticus fed dietary tested probiotic especially $\mathrm{T}_{4}$ compared to the control $\left(\mathrm{T}_{1}\right)$ group (Figure $5 \mathrm{a}$-g), which highly associated with the morphological sexual maturation characteristics (Figure $1 \mathrm{a}-\mathrm{h}$ ) and anatomical sexual maturation signs of testes (Figure 3 a-d). Similarly, these findings are also strongly related with the significantly increased of total testosterone, testes weight, gonado somatic index, sperm quality parameters of adult males' O. niloticus fed Hydroyeast Aquaculture ${ }^{\circledR}$ probiotic reported by Mehrim et al., [29].
Based on the histological findings of ovaries in the present study, fish fed graded levels of the tested probiotic, especially in $T_{7}(10$ $\mathrm{g} \mathrm{Kg}^{1}$ diet). The superiority of this treatment related with its respectable reproductive physiological results, concerning the highest serum progesterone, egg diameter, and highest fecundity of adult females' O. niloticus previously stated by Mehrim et al., [29]. This advantage of $\mathrm{T}_{7}$ among other treatments also may be related with the role of tested Hydroyeast Aquaculture ${ }^{\circledR}$ probiotic to enhance host enzyme secretion which, increase the digestive efficacy of the complex proteins and lipids included in the diet thus, increasing feed digestion and absorption by the host. These findings are strongly agreement with those reported by Tovar et al., [43] and Ghosh et al., [26, 44]. Since, there were positive correlation between the presence of proteins and fatty acids in the brood stock diet and reproductive-related factors such as better oocyte development and maturation, higher rate of vitellogenesis and larger egg size [26, 45]. Moreover, Abasali and Mohamad [46] also reported that the commercial probiotic $\left(\right.$ Primalac $^{\circledR}$ ) could be enhanced the reproductive performance of platy-fish broodstock Xiphophorus maculates during different reproductive stages.

In the present study, the histological examination of adult females' $O$. niloticus ovaries revealed the presence of different development stages of oocytes (Figure $6 \mathrm{a}-\mathrm{f}$ ). These observations were accordingly with those reported by Wallace [47]; West [48]. Whereas, major developmental events can be divided into six phases: oogenesis, primary oocyte growth, cortical alveolar stage, vitellogenesis, maturation and ovulation [38]. Oocytes of all developmental stages were found throughout the reproductive cycle indicating that T. zillii possess asynchronous ovaries [49]. Oocytes undergo the same basic pattern of growth in all teleost species studied. Even within an individual oocyte, there are likely to be periods when these growth phases overlap [50]. Moreover, even in synchronous ovaries, two or three phases may occur simultaneously [38], where similar structures were also reported by Hussein [51]. Likewise, the microscopic criteria applied in the classification of ovarian development are based on oocyte characteristics such as the formation of cortical alveoli, degree of yolk accumulation and nuclear migration [35].

The immunostimulatory effects of several feed additives differ by fish species, route of management, dose, duration and association with other immunostimulants were intensively reported [52]. Generally, the obtained results herein revealed that the probiotic incorporated diets helped to increase the reproductive performance and gonads maturation of the both sexes of adult O. niloticus. Where, the stimulatory role of tested probiotic on appearance the morphological and anatomical alterations and enhancement the histological structure of gonads of both sexes $O$. niloticus may be due to both the activation of the neuroendocrine system that regulates the reproduction process and to local factors that control oocyte development and maturation. These findings are in agreement with those obtained by Ghosh et al., [26] who reported that using $10^{6}-10^{8}$ cells of Bacillus subtilis $\mathrm{g}^{1}$ diet increased the reproductive performance parameters and production of fry from the females of four species of ornamental fishes. Thus, these authors proposed that complex B vitamins synthesized by the probiotic, especially thiamine (vitamin $\mathrm{B}_{1}$ ) and vitamin $\mathrm{B}_{12}$, contribute to reduce the number of dead or deformed offspring. Moreover, Abasali and Mohamad [27] stated that significant differences between the control and probiotic-treated groups 
of $X$. helleri; in the total production of fries per female and the relative fecundity seriously related with the probiotic treatment.

Finally, positive effects of tested probiotic herein on the morphological, anatomical and histological traits of gonads of adult $O$. niloticus males and females were significantly detected compared to fish fed free diet of probiotic. The effectiveness of tested probiotic may be mainly depending on several factors i.e. the formula of probiotic, supplementation form, vector of administration, dosage level and duration of application [53]. Where, Merrifield and Ringø [11] also reported that the efficacy of probiotic is host, strain, dosage and exposure time dependent. Moreover, different modes of action are documented on the potential probiotic like antagonism to pathogens [54, 55], ability of cells to produce metabolites (like vitamins) and enzymes, colonization or adhesion properties [56], and enhance the immune system [57]. Additionally, probiotic bacteria established in the gut enhance broodstock and larval nutrition by synthesizing essential nutrients (proteins and essential fatty acids) and enzymes (amylase, protease and lipase) [58]. Whereas, probiotic bacteria in the fish intestine improves host enzyme secretion by the superior maturation of fish intestinal secretory cells [43], which increases the digestive efficacy of the complex proteins and lipids included in the diet. Proteins and fatty acids are very important constituents of the yolk and their presence in diet consequently supports good oocyte development and maturation and a higher rate of vitellogenesis [59]. Besides the regulation of reproductive physiology, essential fatty acids also supply energy to tolerate the spawning activities. Probiotic bacteria also produce B group vitamins [60], which could have played a key role in the elevated reproductive performance of the probiotic feed-fed fish [61].

\section{Conclusion}

From the obtained results, it could be concluded the usefulness of dietary addition of a newly commercial probiotic Hydroyeast Aquaculture ${ }^{\circledR}$ for enhancement the morphological, anatomical of sexual maturation and histological characteristics of the gonads in the pre-spawning stage at level of $15 \mathrm{~g}$ probiotic $\mathrm{Kg}^{1} \operatorname{diet}\left(\mathrm{T}_{4}\right)$ and $10 \mathrm{~g}$ probiotic $\mathrm{Kg}^{1}$ diet $\left(\mathrm{T}_{7}\right)$ for adult O. niloticus males and females, respectively. Additionally, more advanced studies related with the effect of functional feed additives, including probiotic, prebiotic, synbiotic, micro- and macro algae, and organic acids on different fish reproduction stages, particularly in pre-spawning stage, also on the broodstock nutritional-reproductive relationship, and its effects on embryo and larval development, survival and growth, especially in marine fish hatcheries are seriously required. Thus, it is expected that probiotics will be used to reduces the cost of fish hatcheries by improving the reproductive performance of broodstock, and decreasing the feed cost per unit of producing healthy fish offspring, that consequentially lead to the environmentally sustainable aquaculture industry.

\section{References}

[1]. Subasinghe RP, Curry D, McGladdery SE, Bartley D. Recent technological innovations in aquaculture. FAO Fisheries Circular. 2003;886:85.

[2]. FAO (Food and Agriculture Organization); 2018. The state of world fisheries and aquaculture 2016 (SOFIA): Contributing to food security and nutrition for all. FAO of the United Nations, Rome, Italy; Available from: www.fao. org/3/i9540en/I9540EN.pdf

[3]. GAFRD (General Authority for Fishery Resources Development); 2016.
Fish Statistics Yearbook 2015. Ministry of Agriculture and Land Reclamation, Cairo, Egypt. Available from: http://www.gafrd.org/posts/979230

[4]. Telli GS, Ranzani-Paiva MJ, de Carla Dias D, Sussel FR, Ishikawa CM, Tachibana L. Dietary administration of Bacillus subtilis on hematology and non-specific immunity of Nile tilapia Oreochromis niloticus raised at different stocking densities. Fish Shellfish Immunol. 2014 Aug;39(2):305-11. doi: 10.1016/j.fsi.2014.05.025. PubMed PMID: 24878743.

[5]. Ibrahem MD. Evolution of probiotics in aquatic world: potential effects, the current status in Egypt and recent prospectives. J Adv Res. 2015 Nov;6(6):765-91. doi: 10.1016/j.jare.2013.12.004. PubMed PMID: 26644914.

[6]. Barrows FT, Hardy RW. Feed Additives: Encyclopedia of Aquaculture. 1st ed. John While and Sons Pty Ltd: Australia; 2000.

[7]. Bai SC, Katya K, Yun H. Additives in aquafeed: an overview. In Feed and Feeding Practices in Aquaculture. 1st ed. Woodhead Publishing: Elsevier; 2015. p. 171-202.

[8]. Encarnação P. Functional feed additives in aquaculture feeds. InAquafeed formulation. 1st ed. Academic Press: Elsevier; 2015. p. 217-237.

[9]. Pigott GM, Tucker BW. Special feeds. In Fish Nutrition. 3rd ed. 2003. p. 651-669.

[10]. FAO/WHO (Food and Agriculture Organization / World Health Organization); 2002. Guidelines for the evaluation of probiotics in food (Joint FAO/ WHO working group report on drafting guidelines for the evaluation of probiotics in food. Available from: www.fao.org/3/a-a0512e.pdf

[11]. Merrifield DL, Ringo E. Aquaculture nutrition: gut health, probiotics and prebiotics. 1st ed. John Wiley \& Sons: USA; 2014 Aug 13.

[12]. Pandiyan P, Balaraman D, Thirunavukkarasu R, George EG, Subaramaniyan K, Manikkam S, Sadayappan B. Probiotics in aquaculture. Drug Invent Today. 2013 Mar 1;5(1):55-9.

[13]. Sullivan $\AA$, Nord CE. The place of probiotics in human intestinal infections. Int J Antimicrob Agents. 2002 Nov;20(5):313-9. PubMed PMID: 12431865.

[14]. Senok AC, Ismaeel AY, Botta GA. Probiotics: facts and myths. Clinical Clin Microbiol Infect. 2005 Dec;11(12):958-66. PubMed PMID: 16307549.

[15]. Balcázar JL, Vendrell D, De Blas I, Ruiz-Zarzuela I, Gironés O, Múzquiz JL. In vitro competitive adhesion and production of antagonistic compounds by lactic acid bacteria against fish pathogens. Vet Microbiol. 2007 Jun 21;122(3-4):373-80. PubMed PMID: 17336468

[16]. Standen BT, Peggs DL, Rawling MD, Foey A, Davies SJ, Santos GA, et al. Dietary administration of a commercial mixed-species probiotic improves growth performance and modulates the intestinal immunity of tilapia, Oreochromis niloticus. Fish Shellfish Immunol. 2016 Feb;49:427-35. doi: 10.1016/j.fsi.2015.11.037. PubMed PMID: 26672904.

[17]. Ramos MA, Batista S, Pires MA, Silva AP, Pereira LF, Saavedra MJ, et al. Dietary probiotic supplementation improves growth and the intestinal morphology of Nile tilapia. Animal. 2017 Aug; 11(8):1259-1269. doi: $10.1017 /$ S1751731116002792. PubMed PMID: 28077192.

[18]. Lalloo R, Ramchuran S, Ramduth D, Görgens J, Gardiner N. Isolation and selection of Bacillus spp. as potential biological agents for enhancement of water quality in culture of ornamental fish. J Appl Microbiol. 2007 Nov;103(5):1471-9. PubMed PMID: 17953558.

[19]. Das S, Mondal K, Haque S. A review on application of probiotic, prebiotic and synbiotic for sustainable development of aquaculture. JEZS 5(2):422429.

[20]. Mehrirn AL. Effect of Dietary Supplementation of Biegen (Commercial IYobiotic) on Mono-Sex Nile ti la pin Orcockromis niloticus under Different Stocking Densities. JFAS. 2009;4(6):261-73.

[21]. Garg SK. Effect of Dietary Probiotic Mix (SPILAC) on Growth Performance and Nutritive Physiology of Nile tilapia, Oreochromis niloticus (Linn.) under Laboratory Conditions. IJFAS. 3(2):440-446.

[22]. Li XQ, Zhu YH, Zhang HF, Yue Y, Cai ZX, Lu QP, et al. Risks associated with high-dose Lactobacillus rhamnosus in an Escherichia coli model of piglet diarrhoea: intestinal microbiota and immune imbalances. PloS one. 2012 Jul 27;7(7):e40666.

[23]. Pirarat N, Pinpimai K, Endo M, Katagiri T, Ponpornpisit A, Chansue $\mathrm{N}$, et al. Modulation of intestinal morphology and immunity in nile tilapia (Oreochromis niloticus) by Lactobacillus rhamnosus GG. Res Vet Sci. 2011 Dec;91(3):e92-7. doi: 10.1016/j.rvsc.2011.02.014. PubMed PMID: 21536310.

[24]. Standen BT, Rodiles A, Peggs DL, Davies SJ, Santos GA, Merrifield DL. Modulation of the intestinal microbiota and morphology of tilapia, Oreochromis niloticus, following the application of a multi-species probiotic. Appl Microbiol Biotechnol. 2015 Oct;99(20):8403-17. doi: 10.1007/ s00253-015-6702-2. PubMed PMID: 26115752.

[25]. Lombardo F, Gioacchini G, Carnevali O. Probiotic-based nutritional effects on killifish reproduction. Fish Aquacult J. 2011 Jan 1.

[26]. Ghosh S, Sinha A, Sahu C. Effect of probiotic on reproductive performance 
in female livebearing ornamental fish. Aquacult Res. 2007 Mar;38(5):51826.

[27]. Abasali H, Mohamad S. Effect of dietary supplementation with probiotic on reproductive performance of female livebearing ornamental fish. Res J Anim Sci. 2010;4(4):103-7.

[28]. Carnevali O, Avella MA, Gioacchini G. Effects of probiotic administration on zebrafish development and reproduction. Gen Comp Endocrinol. 2013 Jul 1;188:297-302. doi: 10.1016/j.ygcen.2013.02.022. PubMed PMID: 23500006

[29]. Mehrim AI, Khalil FF, Hassan ME. Hydroyeast Aquaculture as a reproductive enhancer agent for the adult Nile tilapia (Oreochromis niloticus Linnaeus, 1758). Fish Physiol Biochem. 2015 Apr;41(2):371-81. doi: 10.1007/ s10695-014-9989-5. PubMed PMID: 25240678.

[30]. Wahbi OM, Sangak Y. Enhancement of Reproductive Performance of Nile Tilapia Oreochromis niloticus using Phytobiotic Spirulina platensis. J Biol Sci. 2017;17(7):305-11.

[31]. Dawood MA, Koshio S, Abdel-Daim MM, Van Doan H. Probiotic application for sustainable aquaculture. Rev Aquacult. 2018.

[32]. Roberts RJ. Fish Pathology. 3rd ed. Saunders WB: London; 2001.

[33]. Webster CD, Lim C, editors. Tilapia: biology, culture, and nutrition. CRC Press; 2006 Aug 21.

[34]. Nandlal S, Pickering T. Tilapia fish farming in Pacific Island countries: Tilapia hatchery operation. 1st ed. Secretariat of the Pacific Community and Marine Studies Program, The University of the South Pacific, Laucala Campus: Suva, Fiji; $2004 \mathrm{Vol} 1$.

[35]. Bucholtz RH, Tomkiewicz J, Dalskov J. Manual to determine gonadal maturity of of herring (Clupea harengus L.). 2008.

[36]. Msiska OV. The histology of mature gonads of Oreochromis (Nyasalapia) karongae (Trewavas). Afr J Ecol. 2002 Jun;40(2):164-71.

[37]. Groman DB. Histology of Striped Bass. 1st ed. American Fisheries Society, Bethesda: USA; 1982.

[38]. Tyler CR, Sumpter JP. Oocyte growth and development in teleosts. Rev Fish Biol Fish. 1996 Sep 1;6(3):287-318.

[39]. Loir M, Sourdaine P, Mendis-Handagama SM, Jégou B. Cell-cell interactions in the testis of teleosts and elasmobranchs. Microsc Res Tech. 1995 Dec 15;32(6):533-52. PubMed PMID: 8605400

[40]. Le Gac F, Loir M. Male reproductive system, fish. Encyclopedia of reproduction. 1999;3:20-30.

[41]. Russell LD, Ettlin RA, Sinha Hikim AP, Clegg ED. Mammalian spermatogenesis: Histological and histopathological evaluation of the testis. 1st ed. Cache River Press, Clearwater: USA; 1993.

[42]. Hess RA, de Franca LR. Spermatogenesis and cycle of the seminiferous epithelium. Adv Exp Med Biol. 2008;636:1-15. doi: 10.1007/978-0-38709597-4_1. PubMed PMID: 19856159.

[43]. Tovar D, Zambonino J, Cahu C, Gatesoupe FJ, Vázquez-Juárez R, Lésel $R$. Effect of live yeast incorporation in compound diet on digestive enzyme activity in sea bass (Dicentrarchus labrax) larvae. Aquaculture. 2002 Jan 21;204(1-2):113-23.

[44]. Ghosh S, Sinha A, Sahu C. Dietary probiotic supplementation in growth and health of live-bearing ornamental fishes. Aquaculture Nutrition. 2008 Aug; 14(4):289-99.
[45]. Ling S, Hashim R, Kolkovski S, Chong Shu-Chien A. Effect of varying dietary lipid and protein levels on growth and reproductive performance of female swordtails Xiphophorus helleri (Poeciliidae). Aquacult Res. 2006 Sep;37(13):1267-75

[46]. Abasali H, Mohamad S. Effect of dietary probiotic level on the reproductive performance of female platy Xiphophorus maculatus. Agriculture J. 2011;6(3):119-23.

[47]. Wallace RA. Vitellogenesis and oocyte growth in nonmammalian vertebrates. Dev Biol (N Y 1985). 1985;1:127-77. PubMed PMID: 3917200.

[48]. West G. Methods of assessing ovarian development in fishes: a review. Aust J Mar Freshwat Res. 1990;41(2):199-222.

[49]. Wallace RA, Selman K, Greeley MS, Begovac PC, Lin YWP. Current status of oocyte growth: The 3rd International Symposium on the Reproductive Physiology of Fish. Memorial University of Newfoundland, Canada. 1987 August 2-7;167-177.

[50]. Wallace RA, Selman K. Physiological aspects of oogenesis in two species of sticklebacks, Gasterosteus aculeatus L. and Apeltes quadracus (Mitchill). J Fish Biol. 1979 Jun;14(6):551-64.

[51]. Hussein KA . Gonadal maturation and fecundity of a fish with partial spawning (Tilapia nilotica L.). Arab J Sci Res. 1984;2:683-699.

[52]. Dawood MA, Koshio S, Esteban MÁ. Beneficial roles of feed additives as immunostimulants in aquaculture: a review. Rev Aquacult. 2018 Dec;10(4):950-74.

[53]. Mohapatra S, Chakraborty T, Prusty AK, Das P, Paniprasad K, Mohanta $\mathrm{KN}$. Use of different microbial probiotics in the diet of rohu, Labeo rohita fingerlings: effects on growth, nutrient digestibility and retention, digestive enzyme activities and intestinal microflora. Aquacult Nutr. 2012 Feb;18(1):1-1.

[54]. Gram L, Melchiorsen J. Interaction between fish spoilage bacteria Pseudomonas sp. and Shewanella putrefaciens in fish extracts and on fish tissue. J Appl Bacteriol. 1996 Jun;80(6):589-95. PubMed PMID: 8698659.

[55]. Ringø E, Vadstein O. Colonization of Vibrio pelagius and Aeromonas caviae in early developing turbot (Scophthalmus maximus L.) larvae. J Appl Microbiol. 1998 Feb;84(2):227-33. PubMed PMID: 9633637.

[56]. Olsson JC, Westerdahl AL, Conway PL, Kjelleberg ST. Intestinal colonization potential of turbot (Scophthalmus maximus)-and dab (Limanda limanda)-associated bacteria with inhibitory effects against Vibrio anguillarum. Appl Environ Microbiol. 1992 Feb;58(2):551-6. PubMed PMID: 1610180.

[57]. Perdigon G, Alvarez S, Rachid M, Agüero G, Gobbato N. Immune system stimulation by probiotics. J Dairy Sci. 1995 Jul;78(7):1597-606. PubMed PMID: 7593855.

[58]. Irianto A, Austin B. Probiotics in aquaculture. J Fish Dis. 2002 Nov;25(11):633-42.

[59]. Dahlgren BT. The effects of three different dietary protein levels on the fecundity in the guppy, Poecilia reticulata (Peters). J Fish Biol. 1980;16:83-97.

[60]. Goldin BR, Gorbach SL. Probiotics for humans: Probiotics. 1st ed. Chapman \& Hall: UK; 1992.

[61]. Coves D, Audineau P, Nicolas JL. Rotifer rearing technology: Aquaculture. 1st ed. Ellis Harwood, UK; 1990. 